\title{
EBITORIAL
}

\section{A MATTER FOR CONCERN}

IT IS A MATTER for concern that during the past fifteen years the increase in the medical population required to provide services to a growing Canadian population has been achieved only through the immigration of qualified physicians from other lands. It must further be a matter of concern to anaesthetists that a significant proportion of the candidates for training in the specialty during the same period have been immigrants. The danger in this situation lies, of course, in the fact that this source of trained physicians is limited-that it is, in fact, already exhausted. The physicians required to care for the anticipated growth of the Canadian population in the future must come from our own medical schools, and future trainees in the specialty of anaesthesia must be drawn from the graduates of our own schools.

During the past fifteen years too few of our own graduates have entered the specialty of anaesthesia. If this trend should continue, there will result a most serious shortage of qualified anaesthetists during the next decade. This will be the more serious because, with the growth of our smaller urban centres and the increasing supply of trained surgeons, a greater volume of surgery requiring the highest degree of anaesthetic skill and knowledge will be done in these areas. It is essential that more of the best graduates of Canadian medical schools should be attracted to the study of the specialty.

Our failure in the past to attract a larger number of bright young men to the study and practice of anaesthesia undoubtedly reflects the failure of teachers and practising anaesthetists to impress students and internes with the scope, challenge, and importance of anaesthesia. This requires not only imagination in presentation, but time and facilities. Imagination tends to wear thin in the teacher who must carry a full load of clinical work, who is chronically tired from loss of sleep, who has no time to think. To resolve this problem we require more teachers of anaesthesia in our universities adequately compensated to permit them to make teaching a vocation rather than a spare time.avocation; and further, we require adequate clinicall investigation and laboratory facilities in these departments, not only to seek ánswers to the endless procession of problems in anaesthesia, but at the same time to demonstrate to the student and interne the interest and challenge of the specialty. Without these we will find ourselves unable to provide the anaesthetists which will be required by the Canada of 1970. 


\section{UN FAIT INQUIETANT}

N'EST-CE-PAS Un FAIT. INQUí́tant que, au cours des quinze dernières années, l'augmentation du nombre de médecins requis pour assurer les soins à notre population canadienne toujours croissante n'ait pu se réaliser que par l'immigration de médecins étrangers quālifiés. Pour les anesthésistes, ce fait doit être encore bien plus inquiétant car, au cours de cette même période, une bonne proportion des candidats à l'entraînement dans cette spécialité était des étrangers. La rançon de cette situation réside dans le fait que l'apport des médecins entraînés est limité et que, de fait, il est déjà épuisé. Les médecins dont on aura besoin pour traiter, à l'avenir, la population canadienne croissante devront sortir de nos écoles de médecine et les candidats futurs dans la spécialité d'anesthésie devront se recruter parmi les gradués de nos écoles.

De plus, au cours des quinze dernières années; un trop petit nơmbre de nos gradués se sont dirigés vers l'anesthésie. Si cette tendance persiste, il vá en résulter, au cours de la prochaine décade, une diminution alarmante du nombre d'anesthésistes qualifiés. Et cela va devenir d'autant plus sérieux que le nombre de petits centres urbains augmente ainsi que le nombre de chirurgiens qualifiés et, dans ces endroits, une augmentation du volume de la chirurgie va exiger des anesthésistes hautement qualifiés, adroits et renseignés. Il devient donc essentiel qu'un plus grand nombre de nos brillants jeunes médecins 'se dirigent vers la spécialité de l'anesthésie.

Le fait que nous n'ayons pas réussi, dans le passé, à attirer vers la pratique de l'anesthésie un plus grand nombre de nos brillants jeunes médecins est un indice de l'échec, de la part des professeurs et de la part des anesthésistes pratiquant, auprès des étudiants et des internes, à promouvoir l'étendue, le défi et l'importance de l'anesthésie. Pour ce faire, il faut non seulement de l'imàgination dars la présentation, mais aussi du temps et des facilités. Sans doute, l'imagination diminue chez le professeur qui doit accomplir du travail clinique à temps complet, qui, à l'état chronique, est fatigué par manque de sommeil et qui n'a même pas le temps de penser. Pour résoudre ce problème, nous exigeons, de la part de nos universités, un plus grand nombre de professeurs adéquatement rémunérés pour leur permettre de faire de l'enseignement: une vocation et non pas une occupation des temps libres; bien plus, dans ces départements, nous exigeons des facilités de laboratoire et d'investigation clinique adéquates non seulement pour trouver des réponses aux problèmes innombrables qui seposent en anesthésie, mais, aussi, pour pouvoir démontrer aux étudiants et aux internes l'intérêt de la spécialité et le défi qu'elle relève. Sans ces conditions, nous nous verrons dans l'impossibilité de produire les anesthésistes dont le Canada aura besoin en $\mathbf{1 9 7 0 .}$ 